AGRO EKONOMI, Vol 29, Issue 2, December 2018, Page. 323-334

DOI : http://doi.org/ 10.22146/ae.36525

ISSN 0215-8787 (print), ISSN 2541-1616 (online)

Available at https://jurnal.ugm.ac.id/jae/

\title{
FACTORS AFFECTING FARMER EXCHANGE RATE OF SUGARCANE FARMER PLASMA IN PTPN XI
}

\section{Faktor-faktor yang Mempengaruhi Nilai Tukar Petani Tebu Plasma PTPN XI}

\author{
Muhammad Zul Mazwan ${ }^{1}$, Masyhuri² \\ ${ }^{1}$ Agribusiness, Universitas Muhammadiyah Malang \\ ${ }^{2}$ Faculty of Agriculture, Universitas Gadjah Mada \\ ${ }^{1} \mathrm{Jl}$. Raya Tlogomas No.26 Malang, Jawa Timur \\ ${ }^{2}$ Jl. Flora No. 1 Bulaksumur, Yogyakarta \\ m.zulmazwan94@gmail.com
}

Submitted: 15 August 2018; Revised: 12 September 2018; Accepted: 22 November 2018

\begin{abstract}
This study aimed to determine the exchange rate and its affecting factors of plasma sugarcane farmers in PTPN XI. This research involved 95 farmers each in wet and dry (moorland) area. The concepts of this research are the concept of subsistence and multiple linear regression analysis method. The result shows that the exchange rate of plasma sugarcane farmers in PTPN XI is $90.87 \%$ for those planting in the wet field, and $90.01 \%$ in the moorland. It means that the average welfare status of sugarcane farmers can be categorized as not prosperous. Factors increasing plasma sugarcane farmer's exchange rate on the paddy field are sugarcane farm productivity, land area and rendement of the sugarcane. In addition, the influential factors on the dry land are land area and the yield of sugarcane. On the opposite, factors descreasing the plasma sugarcane farmers' exchange rate in the paddy field are farmer's experience, price of seed, price of inorganic fertilizer and price of labor, while on dry land are the number of family members and cost of labor. The government needs to raise the Highest Retail Price of sugar. Government programs to support the production facility incentive in sugarcane farming activities are required, intended to decrease the production cost of sugarcane and encourage farmers to improve the FER of plasma sugarcane. Agricultural intensification efforts can be conducted by adding the inputs that are able to increase the FER.
\end{abstract}

Keyword: farmer's exchange rate, sugarcane farmers, welfare

Mazwan, M.Z. \& Masyhuri (2018) Factors Affecting Farmer Exchange Rate of Sugarcane Farmer Plasma in PTPN XI. Agro Ekonomi, 29(2) : 323-334

\section{INTISARI}

Penelitian ini bertujuan untuk mengetahui nilai tukar petani tebu plasma PTPN XI dan faktor-faktor yang mempengaruhinya. Penelitian ini menggunakan responden sebanyak 95 petani tebu lahan sawah dan 95 petani tebu lahan tegalan. Konsep yang digunakan pada penelitian nilai tukar petani ini yaitu konsep subsisten dan regresi linier berganda. Hasilnya, nilai tukar petani tebu plasma PTPN XI pada lahan sawah sebesar 90,87\% dan lahan tegalan sebesar 90,01\%. Artinya rata-rata petani tebu dalam keadaan tidak sejahtera. 
Faktor-faktor yang meningkatkan nilai tukar petani lahan sawah yaitu produktivitas tebu, luas lahan dan rendemen tebu. Sedangkan pada lahan tegalan yaitu luas lahan dan rendemen tebu. Adapun faktor-faktor yang menurunkan nilai tukar petani tebu lahan sawah yaitu pengalaman petani, harga bibit, harga pupuk anorganik dan upah tenaga kerja. Sedangkan pada lahan tegalan yaitu jumlah anggota keluarga dan upah tenaga kerja. Pemerintah perlu menaikkan Harga Eceran Tertinggi gula. Program pemerintah untuk mendukung insentif fasilitas produksi diperlukan untuk menurunkan biaya produksi tebu dalam memberikan motivasi untuk meningkatkan NTP. Upaya intensifikasi input juga perlu dilakukan dengan menambahkan input produksi yang mampu meningkatkan NTP.

Kata Kunci: kesejahteraan, nilai tukar petani, petani tebu

\section{INTRODUCTION}

Agriculture sector has important roles in the economic activities of Indonesia. According to Indonesian's Central Bureau of Statistics, this condition can be proved through its contribution to the Gross Domestic Product (GDP) that has a decent amount, i.e. $13.62 \%$ in 2015 or ranked second after Manufacturing Industry sector. One of the agricultural subsectors having big potentials to develop is plantation subsector on sugarcane commodities. The Directorate General of Plantations stated that the cane-based sugar industry is one of the sources of income for 1.07 millions of sugarcane farmers and 0.28 millions of workers in the national sugar industry. In addition, sugar is also one of the primary needs for the major communities, which provides sufficient level of welfare for them specifically farmers since it becomes one of the important aspects of the sustainability of sugarcane production is the level of farmer welfare. The Directorate General of Plantations mentioned that the sugar cane production center in Indonesia in 2013-2017 was East Java Province. Its production reached $1,186,515$ tons or $48.13 \%$ of the national sugarcane production in 2017.

In order to see the farmer welfare level, FER (Farmer Exchange Rate) is the instrument that is used. FER is associated with the capability and purchasing power of farmers in funding their household lives (Syekh, 2013). On Indonesian's Central Bureau of Statistics, FER in East Java within 2009-2016 showed a downward trend of 100, 93, 96, 97, 94, 104, 101 and 100 respectively. According to the data, the welfare of smallholder farmers including sugar cane farmers is not prosperous. In fact, the sugarcane farmers in the scope of PTPN XI experienced a decrease in their purchasing power. In addition to the decreasing production and income in the last three years, the sugarcane farmers also experienced a high rate of expenditure index spent to fulfill their household needs. Data from Indonesian's Central Bureau of Statistics shows that inflation rate for the last 3 years in Indonesia was 3.35 (2015), 
3.02 (2016) and 3.61 (2017). According to

Nurasa \& Rachmat (2013), the number of income proportions of farmers households from agricultural sector will influence the number of farmer exchange rate which is highly associated with the role of agriculture in fulfilling the needs of farmers households. Bantilan et al., (2018) added that the high and low rates of FER are influenced by production, household consumptions, sugarcane sales and the utilization of quality seeds. Therefore, this research analyzes farmer exchange rate and the determinant factors as the indicators of sugarcane farmer's welfare in East Java, especially the plasma sugarcane farmers under PT Perkebunan Nusantara (PTPN) XI.

\section{METHODS}

\section{Data and Location}

The fundamental method in this research was descriptive analysis method with survey technique. PTPN XI has 16 units of sugar factory spread in three regions: west, middle, and east region. The selection of the research locations was done purposively. The research locations were in six sugar factories of PT. Perkebunan Nusantara XI conducted in January 2018. The six selected locations were PG. Purwodadi (Magetan Regency) and PG. Pagottan (Madiun Regency) represent the west region, PG. Djatiroto (Lumajang Regency) and PG. Semboro (Jember
Regency) represented the middle region, PG, while sembagoes (Situbondo Regency) and PG. Pradjekan (Bondowoso Regency) represented the east region.

Observation, interview, and documentation/recording were carried out during the data collection. The selected respondents were sugarcane farmers in wet and dry field of PTPN XI. In this context, wet field means the field where usually is planted by paddy so that the water covers the soil, while the dry field is defined as moorland which require limited water. The selection of the respondents was conducted purposively (purposive sampling). The researcher involved 190 farmers as the respondents, comprising of 95 sugarcane farmers for each type of land. According to Plantation Research and Development Center that the sugarcane productivity in wet land (94 ton/ha) is higher than the sugarcane productivity in dry land (69 ton/ ha). It was done to compare the welfare level between farmers of both types of land.

\section{Method of Analysis}

The concept of Farmer Exchange Rate (FER) is defined as the price index received by farmers with the price index paid by farmers or the ratio between the revenue of sugarcane farming and the expenditure of farmer's households. According to the calculation concept, if the data being used were cross section data, the concept of exchange value put 
into usage was the concept of subsistent calculation describing the exchange power of farming revenue towards the expenditure of farmers to fulfill their life needs. According to Nurasa \& Rachmat (2013), the explanation above can be formulated as follows:

$$
\begin{aligned}
\mathrm{FER} & =\frac{\mathrm{Is}}{\mathrm{Es}+\mathrm{Ef}+\mathrm{Eg}} \times 100 \% \\
\mathrm{NTP} & =\frac{\mathrm{Yut}}{\text { Cut }+ \text { Cp }+ \text { Cnp }} \times 100 \%
\end{aligned}
$$

Notes:

FER $=$ Farmers Exchange Rate

Is = Income from sugarcane farming

Es = Farmer's expenditure for sugarcane farming

$\mathrm{Ef}=$ Farmer's expenditure for food

$\mathrm{Eg}$ = farmer's expenditure for good (non food)

According to Indonesian's Central Bureau of Statitstics (2017), the criteria of FER value can be interpreted as follows: FER $>100$ means farmers have a surplus and prosperity

$\mathrm{FER}=100$ means farmers reach BEP but do not yet prosper

FER $<100$ means farmers are deficit and not prosperous

The average difference test (t-test) was done to compare the significant mean between wet and dry field. The analysis of factors influencing the farmer exchange rate was performed through multiple linear regression method. The estimation towards the correlation between dependent and independent variables is explained as follows:

$\operatorname{Ln} \mathrm{FER}=\alpha+\operatorname{Ln} \beta_{1} X_{1}+\operatorname{Ln} \beta_{2} X_{2}+\operatorname{Ln}$ $\beta_{3} X_{3}+\operatorname{Ln} \beta_{4} X_{4}+\operatorname{Ln} \beta_{5} X_{5}+\operatorname{Ln} \beta_{6} X_{6}+$ $\operatorname{Ln} \beta_{7} X_{7}+\operatorname{Ln} \beta_{8} X_{8}+\operatorname{Ln} \beta_{9} X_{9}+\operatorname{Ln} \beta_{10} X_{10}$ $+\operatorname{Ln} \beta_{11} X_{11}+\operatorname{Ln} \beta_{12} X_{12}+\operatorname{Ln} \beta_{13} X_{13}+$ $\operatorname{Ln} \beta_{14} \mathrm{X}_{14}+\mathrm{e}^{\mathrm{u}}$

Notes:

FER $=$ Farmmer's exchange rate in subsistance concept (\%)

$\mathrm{X}_{1}=$ Sugarcane productivity (quintal/ ha)

$\mathrm{X}_{2}=$ Land area (ha)

$\mathrm{X}_{3}=$ Age (years)

$\mathrm{X}_{4}=$ Formal education (years)

$\mathrm{X}_{5}=$ Family menbers (people)

$\mathrm{X}_{6}=$ Farming experiance (years)

$\mathrm{X}_{7}=$ Price of molasses (Rp/quintal)

$\mathrm{X}_{8}=$ Price of seeds (Rp/quintal)

$\mathrm{X}_{9}=$ Price of anorganic fertilizer $(\mathrm{Rp} /$ quintal)

$\mathrm{X}_{10}=$ Price of organic fertilizer $(\mathrm{Rp} /$ quintal)

$\mathrm{X}_{11}=$ Price of pestisides (Rp/littre)

$\mathrm{X}_{12}=$ Cost of labor wage $(\mathrm{Rp} / \mathrm{Hok})$

$\mathrm{X}_{13}=$ Price of rice as representative of comodity prices paid by farmers $(\mathrm{Rp} / \mathrm{kg})$

$\mathrm{X}_{14}=$ Rendement of sugarcane $(\%)$

$\alpha=$ Intercept

$\beta_{1}-\beta_{14}=$ Coefficient regression $X_{1}-X_{14}$

$\mathrm{e} \quad=2,718$

$\mathrm{u}=$ Error

The test on compatibility of regression model used in this research was performed 
through classical assumption tests and statistical test. According to Gujarati, D., N. (1991) the requirements of using cross section data in the classical assumption test are normality test, multicollinearity test, and heteroscedascity test. In addition, the statistical test being used included coefficient of determination $\left(\mathrm{R}^{2}\right), \mathrm{F}$ test, and $t$ test.

\section{RESULTS AND DISCUSSION}

\section{The Analysis of Farmer Exchange Value}

Sugarcane farming was the main source of income for Plasma farmers in PTPN XI. $77.5 \%$ of farmers (sample) work as sugarcane farmer ranging on 3 to 9 hectares land area. Analysis result shows that the average exchange rate of plasma sugarcane farmers of PTPN XI amounted to $90.87 \%$ and $90.1 \%$ on the wet and dry field respectively. This condition shows that the average plasma sugarcane farmers in PTPN XI experienced deficits, meaning that the acquired revenues of sugarcane farming are not able to fulfill the entire household needs of farmers, either foods or non-foods needs. The welfare condition of plasma sugarcane farmers in PTPN XI of East Java is in nonprosperous condition.
The result of the t-test analysis of the farmer exchange rate reveals a significance value of 0.876 , which is greater than the real level of 0.05 . It means that the exchange rates of sugarcane farmers on both types of land are not significantly different. The result of the t-test analysis on revenue per hectare and costs per hectare shows that the significance value was 0.000 , which is lower than the real level of 0.05 . It means that the incomes and cost per hectare on both fields are significantly different. It is because the productivity of wet field (988.94 quintals) is higher than that of dry one (828.09 quintals) although the costs incurred by sugarcane farmers on wet field are higher than those of sugarcane farmers in the dry field. While the costs incurred by sugarcane farming activities on the wet field are larger than that of Dry Field, such as piracy, trenching and making of gutters on arable land. The expenditure on production input i.e. the cost of organic fertilizer was relatively low, while the expenditure on labor cost was the highest component in the production cost. It indicates that sugarcane farming has a higher expenditure rate in paying the cost of labor compared to the ability to purchase other production elements.

Table 1. Analysis of Farmer's Exchange Rate

\begin{tabular}{rrrrrr}
\hline Location & $\begin{array}{c}\text { FER }(\%) \\
{[\mathrm{a} /(\mathrm{b}+\mathrm{c}+\mathrm{d})]}\end{array}$ & $\begin{array}{c}\text { (a) Revenue } \\
(\mathrm{Rp})\end{array}$ & $\begin{array}{c}\text { (b) Cost of } \\
\text { Production }(\mathrm{Rp})\end{array}$ & $\begin{array}{c}\text { (c) Food } \\
\text { Consumption (Rp) }\end{array}$ & $\begin{array}{r}\text { (d) Non-Food } \\
\text { Consumption (Rp) }\end{array}$ \\
\hline Wet Field & 90,87 & 172.685 .111 & 124.084 .611 & 20.374 .970 & 40.395 .082 \\
Dry Field & 90,01 & 137.808 .320 & 99.720 .351 & 20.937 .726 & 34.115 .626 \\
\hline
\end{tabular}

Source: Primary Data Analysis, 2018 
Table 2. Decomposition of Sugarcane FER towards production input cost

\begin{tabular}{|c|c|c|}
\hline $\begin{array}{l}\text { Production Input } \\
\text { Cost (c) }\end{array}$ & Wet Field & Dry Field \\
\hline Land & $33,931,745$ & $23,650,574$ \\
\hline Seed & $3,840,789$ & $2,842,000$ \\
\hline $\begin{array}{l}\text { Inorganic } \\
\text { fertilizer }\end{array}$ & $8,288,465$ & $10,879,490$ \\
\hline $\begin{array}{l}\text { Organic } \\
\text { fertilizer }\end{array}$ & 311,832 & 464,900 \\
\hline Pesticide & 356,484 & 886,324 \\
\hline Labor & $58,543,876$ & $53,754,381$ \\
\hline Forman & $5,418,629$ & $2,805,880$ \\
\hline $\begin{array}{l}\text { Cost decrease of } \\
\text { farming tools }\end{array}$ & $10,041,894$ & $2,919,141$ \\
\hline Other costs & $3,350,896$ & $1,982,563$ \\
\hline $\begin{array}{c}\text { Sum of } \\
\text { Production Cost }\end{array}$ & $124,084,611$ & $99,720,351$ \\
\hline
\end{tabular}

Source: Primary Data Analysis, 2018

The result of the t-test analysis (significance value) on food expenditure is 0.901 and 0.06 for non-food expenditure, meaning that both values are higher than the real level of 0.05 . It means that food and non-food expenditure incurred by sugar cane farmers on the wet and dry field are not significantly different. It implies that the purchasing power of food and non-food needs as well as the lifestyle of sugarcane farmer households in East Java tends to be the same, even though the farmers are scattered in several different locations.

The largest component of household food expenditure was the cost on side dishes, while the lowest expenditure of non-food consumption was on other staple foods apart from rice. The largest non-food consumption component of households was
Table 3. Decomposition of Sugarcane FER towards food consumption expenditure

\begin{tabular}{lrr}
\hline Food Consumption & Wet Field & \multicolumn{1}{c}{ Dry Field } \\
\hline Rice & $3,897,080$ & $5,184,111$ \\
Staple food except & 254,791 & 264,113 \\
rice & & \\
Side dishes & $8,650,567$ & $8,585,372$ \\
Vegetable and & $3,720,934$ & $2,988,516$ \\
cooking spices & 772,543 & 771,614 \\
Sugar & $1,780,072$ & 822,393 \\
Beverage & $2,374,970$ & $2,718,417$ \\
Others
\end{tabular}

Source: Primary Data Analysis, 2018

education, while the lowest expenditure of non-food consumption was water needs. This condition describes that education is the main concern of sugarcane farmer households, while water does not spend much because it can be fulfilled (low cost) in the research locations.

According to the research results, the largest cost paid by farmers was on the production cost of sugarcane farming followed by the daily needs fulfillment of non-food and food materials. These results are in line with the results of a a study conducted by Yulian et al., (2016) revealing that farmers are spending more of their expenditures on the production costs such as purchasing seeds, fertilizers, and pesticides to manage their lands, therefore, the optimal revenues can be acquired. The increasing rate of price index paid by farmers for these production factors is mostly caused by the increasing rate of land rent, seeds, fertilizers, pesticides, and labors. 
Table 4. Decomposition of Sugarcane FER towards non-food consumption expenditure

\begin{tabular}{lrr}
\hline $\begin{array}{c}\text { Non-food } \\
\text { consumption }\end{array}$ & Wet Field & Dry Field \\
\hline Clothes & $2,626,344$ & $2,184,574$ \\
Healthy care & $1,447,692$ & $1,154,130$ \\
Daily needs & $4,186,277$ & $3,714,737$ \\
Social activity & $3,441,702$ & $3,004,842$ \\
Electricity & $9,322,963$ & $7,294,332$ \\
Waterworks & 102,192 & 164,000 \\
Education & $10,527,080$ & $8,147,404$ \\
Tax & $3,956,266$ & $2,930,284$ \\
Communication & $2,971,702$ & $2,790,547$ \\
Cigarette & $3,075,795$ & $2,424,539$ \\
Others & $4,334,559$ & $1,631,481$ \\
\hline
\end{tabular}

Source: Primary Data Analysis, 2018

The decreasing rate of FER as what occurred in the sample locations of this research is caused by the increasing price of production facilities as the largest part of the sugarcane commodity cultivated by farmers in those locations. A similar argument also has been proposed by Nurasa \& Rachmat (2013) mentioning that the declining rate of FER occurs not only on the consumption goods, but also on the component of production cost. Government policies for farmer welfare improvement are associated with farmer household expenditure and emphasizing on the price of farming production factor in the context of subvention of production input price in the form of subvention provision of production facilities such as seeds and fertilizers as well as the subvention of bank credit interests.

\section{Factors That Determine Exchange Rate}

Before the estimation of multiple regression model, the data or research results were ensured not to be interfered by any classical assumption deviation. According to the results, the significance values of kolmogorov-smirnov $\mathrm{Z}$ are 0.578 on the wet field and 0.760 on the dry field, both are higher than 0.05 . It means that the residual data are distributed normally. While on the multicollinearity test, the VIF value of $<10$ indicated the absence of multicollinearity symptoms on the regression model. In addition, in the heteroscedascity test, the significance values on the explanatory variables were above $\alpha=0.05$, meaning that the independent variables in the regression model do not experience heteroscedascity.

According to these results, it can be concluded that the F-value (11.064) > F- table (1.80) on the wet field, and the F-value (11.928) > F-table (1.80) on the dry field. It means that the entire independent variables influence the dependent variable (the exchange rate of sugarcane farmers) collectively. The $\mathrm{R}^{2}$ values in this research were 0.659 (65.9\%) and $0.676(67.6 \%)$ on on the wet and dry field respectively. According to these results, it can be concluded that the independent variables have $65.9 \%$ of the collective impacts on the improvement of the exchange rate of farmers on the wet field, while the remaining $34.1 \%$ were explained 
Table 5. Analysis value of Multiple Linear Regression Wet Field and Dry Field

\begin{tabular}{|c|c|c|c|c|c|c|}
\hline \multirow[b]{2}{*}{ Variable } & \multicolumn{3}{|c|}{ Wet Field } & \multicolumn{3}{|c|}{ Dry Field } \\
\hline & $\begin{array}{l}\text { Coefficient } \\
\text { regression }\end{array}$ & t-statistic & Sig. & $\begin{array}{c}\text { Coefficient } \\
\text { regression }\end{array}$ & t-statistic & Sig. \\
\hline Constanta & $31.149 * * *$ & 3.185 & 0.002 & 1.605 & 0.180 & 0.858 \\
\hline Productivity $\left(\mathrm{X}_{1}\right)$ & $0.561 * * *$ & 3.899 & 0.000 & 0.205 & 1.302 & 0.197 \\
\hline Land $\left(\mathrm{X}_{2}\right)$ & $0.359 * * *$ & 7.645 & 0.000 & $0.399 * * *$ & 7.477 & 0.000 \\
\hline Age $\left(X_{3}\right)$ & 0.052 & 0.331 & 0.742 & -0.155 & -1.180 & 0.242 \\
\hline Education $\left(\mathrm{X}_{4}\right)$ & -0.049 & -0.478 & 0.634 & -0.085 & -0.917 & 0.362 \\
\hline Family members $\left(\mathrm{X}_{5}\right)$ & 0.005 & 0.077 & 0.939 & $-0.247 * * *$ & -3.711 & 0.000 \\
\hline Farmer's experience $\left(\mathrm{X}_{6}\right)$ & $-0.129 * *$ & -2.551 & 0.013 & 0.029 & 0.115 & 0.908 \\
\hline Price of molasses $\left(\mathrm{X}_{7}\right)$ & 0.328 & 1.427 & 0.158 & 0.157 & 0.495 & 0.622 \\
\hline Price of seed $\left(\mathrm{X}_{8}\right)$ & $-0.822 * * *$ & -2.940 & 0.004 & 0.224 & 1.660 & 0.101 \\
\hline Price of inorganic fertilizer $\left(\mathrm{X}_{9}\right)$ & $-0.776 * * *$ & -2.740 & 0.008 & 0.185 & 0.565 & 0.574 \\
\hline Price of organic fertilizer $\left(\mathrm{X}_{10}\right)$ & -0.465 & -1.389 & 0.169 & -0.041 & -0.415 & 0.679 \\
\hline Price of pesticide $\left(X_{11}\right)$ & -0.093 & -0.979 & 0.330 & -0.558 & -1.163 & 0.248 \\
\hline Cost of labor wage $\left(\mathrm{X}_{12}\right)$ & $-0.689 *$ & -1.691 & 0.095 & $-0.073 *$ & $-1,716$ & 0.090 \\
\hline Price of rice $\left(\mathrm{X}_{13}\right)$ & -0.488 & -1.071 & 0.287 & -0.072 & -0.192 & 0.848 \\
\hline Rendement of sugarcane $\left(\mathrm{X}_{14}\right)$ & $0.969 *$ & 1.990 & 0.050 & $2.156^{* * *}$ & 4.762 & 0.000 \\
\hline $\mathrm{R}^{2}$ & 0.659 & & & 0.676 & & \\
\hline F-statistic & 11.064 & & & 11.928 & & \\
\hline
\end{tabular}

Source: Primary Data Analysis, 2018

Notes:

F-table $=1.80(\alpha=5 \%)$

$\mathrm{t}$-table $=2.63869(\alpha=1 \%), \mathrm{t}$-table $=1.99006(\alpha=5 \%), \mathrm{t}$-table $=1.66412(\alpha=10 \%)$

Significant rate $* * * \alpha=1 \%,{ }^{* *} \alpha=5 \%,{ }^{*} \alpha=10 \%$

by other factors in the model. Also, $67.6 \%$ on the improvement of sugarcane farming production on the dry field and the remaining $32.4 \%$ were explained by other factors outside the model.

When the significance of t-value is bigger than t-table, the difference can be considered as significant, and vice versa. The significant factors are explained as follows. Productivity $\left(\mathrm{X}_{1}\right)$ on the wet field has a regression coefficient of 0.561 , showing that the contribution of $1 \%$ productivity amount will increase the farmer exchange rate by $0.561 \%$ at
$99.8 \%$ trust level. A higher sugarcane productivity produced by farmers will have impacts on the farmer exchange rate as an increasing welfare indicator. The average sugarcane productivity of plasma community sugarcane farmers of PTPN XI is 988.94 quintals on the wet field land and 828.09 quintals on the dry field.

Land $\left(\mathrm{X}_{2}\right)$ has a regression coefficient value on the wet field of 0.359 , showing that $1 \%$ contribution of land width will improve the exchange rate of farmers by $0.358 \%$ in average at $100 \%$ trust level. The larger land being used, the higher farmer 
exchange rate will be. The regression coefficient on the dry field was 0.399 , showing that the $1 \%$ contribution of land width will improve the farmer exchange rate by $0.399 \%$ in average at $100 \%$ trust level. The larger the field being used, the higher farmer exchange rate is. The average land usage of plasma community sugarcane farmers of PTPN XI was 3.54 hectare on the wet field and 3.53 hectare on the dry land. This result is parallel with that of a research conducted by Riyadh (2015) who mentioned that by increasing the width of land, farmers could plant more crops. Therefore, those crops will generate an improvement on crops productivity, which will increase the farmer exchange rate or increase the welfare of farmers.

The variable of family members $\left(\mathrm{X}_{5}\right)$ has regression coefficient value. The variable of the family members on the dry field is -0.247 , which shows that $1 \%$ contribution of dependent family members will decrease the farmer exchange rate by $0.247 \%$ at $100 \%$ trust level. The average number of dependent family members within the dry-field plasma community in PTPN XI is was two. According to Fajri et al., (2016), it is because the more the number of farmers' family members, the more the success in farming, because the family members of farmers are actively involved in farming activities. However, the higher the number of family members, the higher the household expenditure will be. Furthermore, this condition will decrease farmer exchange rates.

Farmer's experience $\left(\mathrm{X}_{6}\right)$ on the wet field has regression coefficient value of -0.129 , showing that $1 \%$ contribution of experience in sugarcane farming will decrease the farmer exchange rate by 0.129 in average at $98.7 \%$ trust level. The average of year's experience of plasma community sugarcane farmers of PTPN XI is 17 years on the wet field and 12 years on the dry land. A high experience of farmers in sugarcane farming leads to the decline in farmers' welfare. It is because when the experience of sugarcane cultivation is higher, farmers tend to have difficulty in accepting innovation and technology as they only follow their habits. It finally has an impact on the high expenditure of production facilities so that the exchange rate of farmers will decrease.

Price of Seed $\left(\mathrm{X}_{8}\right)$ on the wet field has regression coefficient value of -0.822 , showing that $1 \%$ improvement of seed price will decrease the farmer exchange rate by $0.822 \%$ at $99.6 \%$ trust level. This condition is caused by the fact that an increasing price of seed purchased by farmers on the wet field will increase the expenditure of sugarcane farming, decreasing farmers' incomes. The average price of seed charged to plasma sugarcane farmers of PTPN XI is IDR 61,084 per quintal on the wet field and IDR 61,611 per quintal on the dry field.

Price of inorganic fertilizer $\left(\mathrm{X}_{9}\right)$ on the wet field has regression coefficient value of 
-0.733 , indicating that $1 \%$ improvement of non-organic fertilizer price will decrease the farmer exchange rate by $0.776 \%$ at $99.2 \%$ trust level. This condition is in line with a research conducted by Nirmala et al., (2016) who stated that the price of inorganic fertilizer has significant negative influences on farmer exchange value. Therefore, the efforts to improve farmer welfare is by using inorganic fertilizers at local prices under appropriate quality and quantity (Rohmah et al., 2014). The average price of inorganic fertilizer charged to the plasma sugarcane farmers of PTPN XI is IDR 18,626 per quintal on the wet field, and IDR 19,553 per quintal on dry field.

Cost of labor $\left(\mathrm{X}_{12}\right)$ on the wet field has regression coefficient value of -0.689 , showing that $1 \%$ improvement of cost of labor will decrease the farmer exchange rate by $0.689 \%$ at $90.5 \%$ trust level. The regression coefficient value is -0.073 , showing that $1 \%$ improvement of cost of labor on the dry field will decrease the farmer exchange rate by $0.073 \%$ at $91 \%$ trust level. These conditions have proved that if the cost of agricultural labor increases, this will affect the production cost paid by farmers. Therefore, higher production cost paid by farmers can decrease the farmer exchange rate. The average costs of labor received by plasma sugarcane farmers of PTPN XI are IDR 55,369 and IDR 53,656 per working day on the wet dry field respectively.
Rendement of Sugarcane $\left(\mathrm{X}_{14}\right)$ on the wet field has regression coefficient value of 0.969 , showing that $1 \%$ improvement of rendement of sugarcane acquired by farmers will improve the farmer exchange rate by $0.969 \%$ at $95 \%$ trust level. The average rendement of sugarcane obtained by plasma sugarcane farmers of PTPN XI on the wet field was $7.19 \%$, which is ranged between $6-8 \%$. The regression coefficient value of 2.156 shows that $1 \%$ improvement of rendement of sugarcane acquired by farmers on the dry field will improve the farmer exchange rate of about $2.156 \%$ at $100 \%$ trust level. The average rendement of sugarcane acquired by plasma sugarcane farmers of PTPN XI on the dry land was about $7.08 \%$, which is ranged between $5.7-8.89 \%$.

\section{CONCLUSION AND SUGGESTION}

The average farmer exchange rate shows the welfare condition of plasma sugarcane farmers of PTPN XI. This study reveals that the welfare is under non-prosperous condition. The factors increasing the farmer exchange rate of plasma sugarcane farmers on the wet field are farm productivity, land area and rendement of sugarcane, while on Dry Field are land area and yield of sugarcane. On the other hand, the factors that descrease the farmer exchange rate of plasma sugarcane farmers on the wet field are farmer's experience, price of seed, price of inorganic fertilizer and cost of labor, 
while on the dry field are number of family members and cost of labor. The factors that insignificantly influence the farmer exchange rate of the plasma sugarcane farmers of PTPN XI are age, education, sugarcane drops, price of organic fertilizer, cost of labor and price of rice.

Government needs to raise the Highest Retail Price of sugar so that farmers have a strong bargaining position. In addition, various government programs to support the production facility incentive in sugarcane farming activities are required, intended to decrease the production cost of sugarcane and provide motivation to improve the FER of plasma sugarcane of PTPN XI. Agricultural intensification efforts can be implemented by adding the inputs that are able to increase the FER.

\section{REFERENCES}

Bantilan, N. K., Wahyuningsih, M. A., \& Rauf, R. A. (2018). Improved Exchange Rate Farmers through Rice Falied Crop Intensification in Tolitoli, Indonesia. Suistainable Agriculture Research, 7(1), 1-6. https://doi.org/10.5539/sar.v7n1p1

Fajri, M. R., Marwanti, S., \& Rahyu, W. (2016). Analisis Faktor-Faktor Yang Mempengaruhi Nilai Tukar Petani Sebagai Indikator Kesejahteraan Petani Padi di Kabupaten Sragen. Agrista, 4(2), 85-94.
Gujarati, D., N. (1991). Dasar-dasar Ekonometrika. (H. Munandar, Ed.). Jakarta: PT. Gelora Aksara Pratama. Indonesian's Central Bureau of Statistics. (2017). Concepts, Meanings of Numbers and Uses of Farmer Exchange Rates.

Nirmala, A., Hanani, N., \& Muhaimin, A. (2016). Analisis Faktor Faktor yang Mempengaruhi Nilai Tukar Petani Tanaman Pangan di Kabupaten Jombang. Habitat, 27(2), 66-71. https://doi.org/10.21776/ ub.habitat.2016.027.2.8

Nurasa, T., \& Rachmat, M. (2013). Nilai Tukar Petani Padi di Beberapa Sentra Produksi Padi di Indonesia (Rice Farmers Term of Trade Analysis in Some Paddy Producing Areas in Indonesia). Jurnal Agro Ekonomi, 31(2), 161-179.

Riyadh, M. I. (2015). Analisis Nilai Tukar Petani Komoditas Tanaman Pangan di Sumatera Utara (Analysis of Farmers Term of Trade of Crops Commodities in North Sumatra). Jurnal Ekonomi \& Kebijakan Publik, 6(1), 17-32.

Rohmah, W., Suryantini, A., \& Hartono, S. (2014). Analisis Pendapatan dan Tingkat Kesejahteraan Rumah Tangga Petani Tebu Tanam dan 
Agro Ekonomi Vol. 29/Issue. 2, December 2018

Keprsan di Kabupaten Bantul

(Analysis of Income and Welfare of Planting Cane and Ratoon Cane Farm Household in Bantul District). Jurnal Agro Ekonomi, 24(1), 54-65.

Syekh, S. (2013). Peran Nilai Tukar Petani dan Nilai Tukar Komoditi dalam Upaya Peningkatan Kesejahteraan Petani Padi di Provinsi Jambi. Jurnal Bina Praja, 5(4), 253-260. https://
doi.org/10.21787/JBP.05.2013.253260

Yulian, R., Hilmanto, R., \& Herwanti, S. (2016). Nilai Tukar Pendapatan Rumah Tangga Petani Agroforestri di Hutan Kemasyarakatan Bina Wana Jaya I Kesatuan Pengelolaan Hutan Lindung Batutegi Kabupaten Tanggamus. Jurnal Sylva Lestari, $4(2), 39-50$. 